\section{Jehovah's Witnesses and blood transfusions}

SIR

I have been following with interest the series of articles in the fournal of Medical Ethics on the subject of Jehovah's Witnesses and the refusal of blood transfusions. There are a couple of aspects which have not been covered and which I would like to raise.

Most of the discussion has centred around adult Jehovah's Witnesses. However, where children are involved the issues become more complex and emotive. I feel that there is a need to examine the rights and responsibilities of parents in the making of life and death decisions on behalf of their children. Also, there is the question of the extent to which the child should be consulted.

If the decision is made to give child a blood transfusion against his or her parents' wishes, the long term psychological effect on the child should also be taken into account. Depending upon the age of the child, he may also have strong views on the subject as a result of the teaching he has received.

In Jehovah's Witness publications, the administration of an unwanted transfusion is likened to assault or rape. Taking blood is presented as disobedience to a very important divine command. Consequently, it is worth considering how children/ teenagers may view this treatment and also how they may view themselves after having (albeit unwillingly) broken God's law as they see it.

So, while the medical personnel involved may be convinced they have saved the child's life, at the same time consideration needs to be given to the differing perspective of the child himself, his family and his religious community. I wonder whether there have been any studies done of the long term psychological effects on those who received transfusions as children.

Another aspect which has not been covered in the discussion to date is the feelings of the nurses involved in the administration of the transfusion. Tra ditionally, paediatric nurses have worked with parents in caring for thei children while in hospital. Therefore, handling a situation in which the wishes of the parents and child are being overridden is difficult. I read the report of a case in which the nurse administering the transfusion was convinced that it was necessary to save the child's life. At the same time, she was deeply distressed by the obvious distress of the child and his parents. This highlights the need for support for nurses in such situations.

I feel that the discussion in the fournal of Medical Ethics has been very helpful in highlighting the variety of views current among Jehovah's Witnesses on the subject of treatments containing blood. I hope that it will help to make both doctors and Jehovah's Witness patients more aware of the options open to them. Translating this into the best possible care for each individual Witness patient may be more difficult, but this is certainly a step in the right direction.

HELEN M DESCOMBES (MRS)

129 Ballards Rd

Dagenham, Essex RM10 9AR

\section{Hospitalised mentally ill patients vote in} Israel

sir

This is the third time hospitalised mentally ill patients have voted in Israeli elections.

In 1996 the law was changed so that patients, including those in psychiatric hospitals, could participate in elections while hospitalised.

Until that year, hospitalised patients could participate in elections only if released from the hospital to vote at their local polling stations.

The ability of mentally ill patients to participate in the democratic process has aroused interest over a long period of time.

In Israel, the right to vote, granted in 1996, raised questions regarding whether the character of their vote would differ from that of the general society or would be apportioned according to the normal distribution of the vote of the citizenry. ${ }^{2}$

In the 1999 elections, patients again participated; however, their voting rate was conspicuously lower than that of the general population: in a psychiatric hospital in the Tel Aviv area, 29\% of the hospitalised patients voted, compared with $72 \%$ of the general population. ${ }^{3}$

On February 6 2001, a special election was held to choose only the prime minister; members of the knesset (parliament) did not stand for election.

Around $60 \%$ of eligible voters participated in the elections, a relatively low percentage (in Israel).

In the Abarbanel Mental Health Center, a large psychiatric hospital in the Tel Aviv area, only 132 of the 509 patients hospitalised that day, $26 \%$, voted. If the additional 47 patients released for the day followed past patterns and they voted while at home, the rate of voting among the patients might have reached $35 \%$.

This is a low result in comparison with the general population; however, it is similar to the percentage of participants in the 1999 elections. It follows that the percentage of patient participation in these elections did not fall, but rather remained low, as in the past.

It may be that what this shows is that a constant proportion of patients regard themselves as part of society and want to participate in the vote. On the other hand, it could be that they were detached and uninfluenced by the general frame of mind and ambivalence in society which caused many to refrain from voting in this election.

It is time for all the mentally ill to participate in all the actions of society, including voting.

\section{References}

1 Armstrong B.The mentally disabled and the right to vote. Hospital and and the right to vote. Hospital and

2 Community Psychiatry 1976;27:577-82. Elizur A. Hospitalized mentally ill patients vote for the first time. Israel fournal of Psychiatry 1997;34:69-72.

3 Melamed Y, Nehama Y, Elizur A. Hospitalized mentally ill patients' voting in Israel. The Fournal of Forensic Psychiatry 2000; 11:691-5.

DR YUVAL MELAMED Head, Department $5 \mathrm{~A}$ Abarbanel Mental Health Center, Bat Yam,

Lecturer, Tel Aviv University, Faculty of Medicine 